\title{
ОНТОЛОГІЧНІ СХЕМИ НАВЧАЛЬНОЇ ІНФОРМАЦІЇ ДЛЯ ПІДГОТОВКИ ВИСОКОКВАЛІФІКОВАНИХ ЛІКАРІВ І ПРОВІЗОРІВ НА ЕТАПІ БЕЗПЕРЕРВНОГО ПРОФЕСІЙНОГО РОЗВИТКУ
}

Л. Ю. Бабінцева

\author{
Національна медична академія післядипломної освіти імені П. Л. Шупика
}

\section{ONTOLOGICAL SCHEME OF EDUCATIONAL INFORMATION FOR TRAINING HIGHLY QUALIFIED DOCTORS AND PHARMACISTS DURING CONTINUOUS PROFESSIONAL DEVELOPMENT}

\author{
L. Yu. Babintseva \\ National Medical Academy of Postgraduate Education by P. L. Shupyk
}

\begin{abstract}
Розглянуто концептуальні можливості створення онтології з медичних/фармацевтичних знань. Підкреслено, що важливо забезпечити системне вирішення навчальних завдань. Відмічено, що організація інформації в онтології допомагає надалі швидко будувати експертні системи та програми для роботи 3 даними. Запропоновано створення інтегральних цілеорієнтованих онтологій для узагальнення знань із клінічної медицини та фармації, що дозволяє надати навчальній інформації нової якості.
\end{abstract}

Conceptual possibility of creating ontology for medical / pharmaceutical knowledge was considered. It is important to provide systematic solution of educational problems was emphasized. The organization of information in ontology further helps quickly build expert systems and applications to work with data was noted. A creation of integrated goal-oriented ontology's to summarize knowledge of clinical medicine and pharmacy, which allows us to provide educational information of a new quality was proposed.

Вступ. Розвиток наукоємних галузей людської діяльності в сучасному суспільстві супроводжується зростанням ролі комп'ютерних технологій. Сьогодні значно збільшується потік інформації, з'явилася необхідність пошуку нових способів ії̈ зберігання, подання, формалізації та систематизації, а також автоматичної обробки. Тобто зростає інтерес до всеосяжних баз знань, що можливо використовувати для різних практичних цілей. Великий інтерес викликають системи, здатні без участі людини витягти будьякі відомості з тексту. Як результат, на тлі знову виникаючих потреб розвиваються нові технології, покликані вирішити заявлені проблеми.

Проблеми впорядкування накопичених знань і виявлення серед них нових знань $є$ сьогодні одними 3 найважливіших у створенні сучасних технологій навчання. Вони тісно пов'язані з використанням принципів онтології.

Мета роботи: узагальнення ключових понять онтології для підготовки висококваліфікованих лікарів

() Л. Ю. Бабінцева і провізорів на етапі безперервного професійного розвитку.

Методологія дослідження базувалася на аналізі, систематизації та виявленні загальних закономірностей і чинників впливу на проблему впорядкування медичних/фармацевтичних знань.

Основна частина. Загалом під онтологією розуміється система понять деякої предметної області, що представляється як набір сутностей, з'єднаних різними відносинами. Онтології використовуються для формальної специфікації понять і відносин, що характеризують певну галузь знань. Перевагою онтологій як способу представлення знань $€$ їх формальна структура, що спрощує і їх комп’ютерне оброблення.

Важливим $є$ те, що за допомогою онтологій може розв' язуватися низка завдань: уніфікація подання різнорідної інформації; інтеграція додатків користувача; автоматизація міркувань; моделювання й проектування; управління знаннями; інтелектуальний пошук інформації. Додатково онтології можуть слугувати посередниками між користувачем i інформаційною системою, що дозволяє формалі- 
зувати терміни, які застосовуються всіма користувачами.

Контент бази знань із будь-якої навчальної дисципліни повинен узагальнювати як накопичений досвід відносно проблеми, так і власні спостереження.

З точки зору навчальної інформації для підготовки висококваліфікованих лікарів і провізорів на етапі безперервного професійного розвитку, констатуємо, що структури онтології (взагалі, вони відрізняються різним ступенем формалізованості - глосарій; проста таксономія; тезаурус (таксономія з термінами); понятійна структура з довільним набором відносин; повністю аксіоматизована теорія) можуть бути корисними для ефективного передавання знань. Основним фактором і поясненням слугують існуючі в медицині та фармації величезні обсяги інформації. Наприклад, при об'єднанні знань про технологію лікування пацієнта на певний клас захворювань із застосовуваними лікарськими засобами, що містять одну або декілька діючих речовин, обсяги загальних відомостей збільшуються в рази. Зрозуміло, що подібний потік інформації без використання впорядкованих баз знань неможливо ефективно застосовувати при підготовці висококваліфікованих фахівців. Зауважимо, що впорядкованість баз знань надає можливості забезпечення цілеорієнтованих онтологій.

Хоча медичні/фармацевтичні онтології вивчено недостатньо, в багатьох дисциплінах розробляються стандартні онтології, що можуть використовуватися експертами $з$ предметних областей для спільного застосування й анотування інформації у своїй галузі. Відомо про створення та використання в галузі медицини великих стандартних, структурованих словників - SNOMED і семантична мережа Системи уніфікованої медичної мови (the Unified Medical Language System). Також 3'являються великі загальноцільові онтології, хоча дотепер не відпрацьовано ме-

\section{Лiтература}

1. GruberT. Toward Principles for the Design of Ontologies Used for Knowledge Sharing / Thomas Gruber // International Journal of Human and Computer Studies. - 1993. - № 43. P. 907-928.

2. Знання орієнтовні засоби підтримки процесів інформаційного супроводу медичного обслуговування населення (перше повідомлення) / О. П. Мінцер, О. В. Палагін, М. Г. Петренко [та ін.] // Медична інформатика та інженерія. -2011. -№ 1.-С. 22-37.

3. КлещёвА. С. Модель онтологии предметной области: Медицинская диагностика. Часть 1. Неформальное описа- ханізм обліку залежності значення медичної/фармацевтичної інформації від часу їі використання.

Окрім того, складання онтологій дозволяє надати навчальній інформації нової якості.

Застосування онтологічних моделей на практиці також допомагає в організації навчального процесу та загалом діяльності закладу освіти щодо створення та підтримки розподілених систем нормативнодовідкової інформації, ведення словників, довідників і класифікаторів, підтримки системи кодування об'єктів обліку. Онтологія дозволяє зменшити ймовірність накопичення суперечливих даних у стандартній структурі класифікації. Такий підхід гарантує однозначну ідентифікацію ресурсів незалежно від трактувань їх найменувань різними користувачами. Причому при використанні такої системи здійснюється ефективний контроль і верифікація даних, перевірка коректності, повноти та несуперечності даних як на етапі аналізу, так і при занесенні нових елементів даних.

Висновки: 1. Медична галузь знання дуже перспективна у сфері застосування онтологій, оскільки для неї вже створено певну кількість онтологій і структурованих джерел знання, а також присутня безліч текстів, що вимагають обробки.

2. Організація інформації в онтології допомагає надалі швидко будувати експертні системи та програми для роботи $з$ даними.

3. Онтології дозволяють усунути мовний бар'єр при пошуку інформації, полегшуючи роботу фахівців. 3' являється можливість порівнювати описи аналогічних випадків на різних мовах і проводити змістовніші дослідження.

4. Запропоновано створення інтегральних цілеорієнтованих онтологій для узагальнення знань із клінічної медицини та фармації, що дозволяє надати навчальній інформації нової якості.

ние и определение базовых терминов / А. С. Клещёв, Ф. М. Москаленко, М. Ю. Черняховская // НТИ. Сер. 2. 2005. - № 12. - C. 1-7.

4. Никоненко А. А. Обзор баз знаний онтологического типа / А. А. Никоненко // Искусственный интеллект. -2009. -№4. - C. 208-219.

5. Палагин А. В. К вопросу системно-онтологической интеграции знаний предметной области / А. В. Палагин, Н. Г. Петренко // Математические машины и системы. 2007. -№ 3, 4.- - С. 63-75. 